\title{
Spontaneous pneumothorax associated with primary lung cancer: a retrospective study
}

\author{
Walid Abu Arab* and Abdel-maguid Ramadan
}

\begin{abstract}
Background: The occurrence of spontaneous pneumothorax in primary lung cancer patients is infrequent. No exact theory could explain its mechanism of association. It could be either a primary manifestation or a late complication of primary lung cancer. The aim of this study is to analyze the association of the spontaneous pneumothorax with the primary lung cancer.
\end{abstract}

Results: A retrospective revision of patients' files that presented with spontaneous pneumothorax and admitted at the Cardiothoracic Surgery Department during the period between January 2000 and January 2018 was done. Twenty-three patients were included in this study. Seventy-four percent of them were males $(n=17)$. Age ranged between 48 and 77 years (62.3 \pm 7.3 years). Twelve patients (52\%) were known to have advanced primary lung cancer, while seven patients (30\%) had SPnx as a primary presentation for the primary lung cancer that was discovered during radiological assessment for SPnx. The remaining four patients had SPnx and were treated via surgery. In three of them, bullectomy and pleurodesis was performed; the postoperative histo-pathological examination of excised bullae revealed a primary non-small cell lung cancer (NSCLC). While in one patient, who had bullectomy, the primary lung cancer was discovered accidently during surgery.

Conclusion: Pneumothorax as a first manifestation for lung cancer is infrequent. Its relation to the prognosis has not been yet clear. Recurrent spontaneous pneumothorax in old, heavy smoker patient, or emphysema patient should raise the suspicion for the possibility of association of lung carcinoma.

Keywords: Pulmonary carcinoma, Spontaneous, Pneumothorax, Spontaneous pneumothorax

\section{Background}

Spontaneous pneumothorax (SPnx) in young adults is not infrequent $[1,2]$. The overall incidence is estimated to be around $5-10 / 100,000$ per year. It is higher in young adult males (1/500 young males) [3]. SPnx is generally caused by rupture of sub-pleural blebs or emphysematous bullae [4-8]. Meanwhile, it can complicate primary or secondary

\footnotetext{
* Correspondence: walidabuarab@yahoo.com

Meeting Presentation: The preliminary work was presented as an oral presentation at the annual meeting of the World Society of Cardiovascular and Thoracic Surgery (WSCTS2015) that was held at Edinburgh- Scotland during 19-22 September 2015. The abstract of the preliminary work is published on line by the Journal of Cardiovascular Surgery.

Cardiothoracic Surgery Department, Faculty of Medicine, University of Alexandria, Middan Al-Khartoum, Alexandria, Egypt
}

lung tumors $[4,9-16]$. Authors reported that sarcomas are the most common malignant neoplasm that causes pneumothorax $[5,9]$. On contrary, SPnx is rarely related to primary pulmonary carcinomas $[4,12,14]$. The estimated incidence of its occurrence is about $0.03-0.05 \%$ for the primary pulmonary carcinoma $[4,5]$. The aim of this retrospective study is to analyze the association of pneumothorax with the primary lung cancer.

\section{Methods}

Retrospective revision of the files of the patients who presented with SPnx and admitted to the Cardiothoracic Surgery Department during the period from January 2000 to January 2018 was performed following approval

\section{Springer Open}

(0) The Author(s). 2020 Open Access This article is licensed under a Creative Commons Attribution 4.0 International License, which permits use, sharing, adaptation, distribution and reproduction in any medium or format, as long as you give appropriate credit to the original author(s) and the source, provide a link to the Creative Commons licence, and indicate if changes were made. The images or other third party material in this article are included in the article's Creative Commons licence, unless indicated otherwise in a credit line to the material. If material is not included in the article's Creative Commons licence and your intended use is not permitted by statutory regulation or exceeds the permitted use, you will need to obtain permission directly from the copyright holder. To view a copy of this licence, visit http://creativecommons.org/licenses/by/4.0/. 
from the Ethical Research Committee. The files were searched for association of SPnx with primary pulmonary carcinoma. Patients who had SPnx in association with pulmonary metastases were eliminated. Data analysis was performed with the SPSS 22.0 statistical software (SPSS, USA). Quantitative data with normal distribution were expressed as mean $\pm \mathrm{SD}$ and compared by student $t$ test. Categorical data were expressed as frequency and percentage, and assessed by the $X^{2}$ and Wilcoxon rank sum tests for nominal and ordinal variables, respectively $p<0.05$ was considered statistically significant.

\section{Results}

Revision of 2536 files related to patients with SPnx was taken place. Those who have been proven to have primary lung cancer constituted twenty-three patients $(0.9 \%)$ and were included in this study. Seventeen patients $(74 \%)$ were males while female patients constituted only $36 \%$. Age ranged between 48 and 77 years (62.3 \pm 7.3 years). All patients included had CT-Chest as part of evaluation of the recurrent SPnx (Figs. 1 and 2). Twelve patients (52\%) were known to have advanced primary lung cancer and were on therapy, while seven patients (30\%) had the SPnx as a primary presentation for the primary lung cancer, which was discovered during radiological assessment for the SPnx. The remaining four patients had surgery for SPnx. In three of them, bullectomy and pleurodesis were performed; the postoperative histo-pathological examination of the excised bullae revealed a primary non-small cell lung cancer (NSCLC). They received formal lobectomy later. While

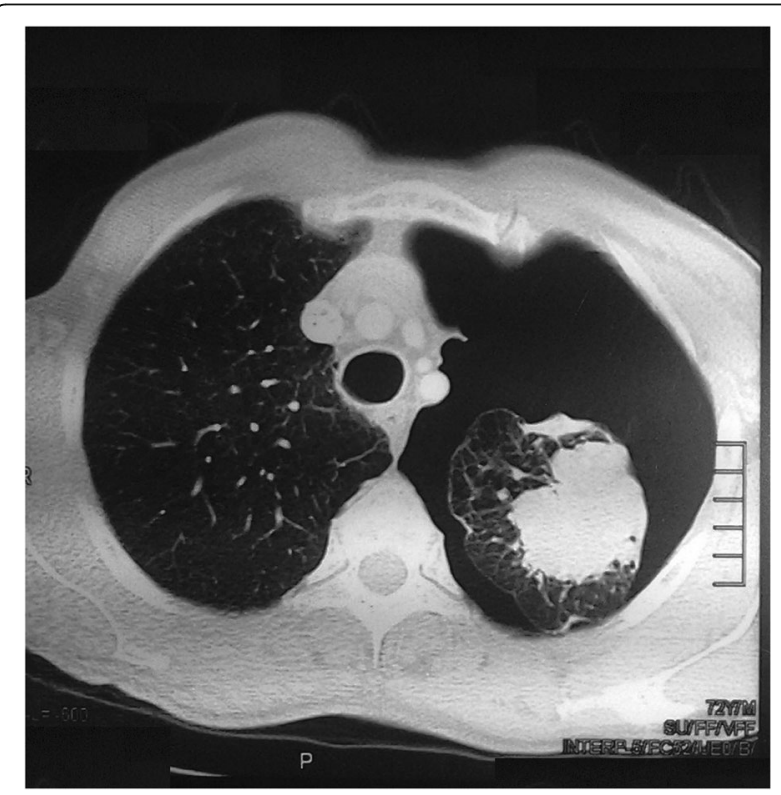

Fig. 1 CT-Chest (pulmonary window) showing mass lesion in the middle left lung zone with partial pneumothorax

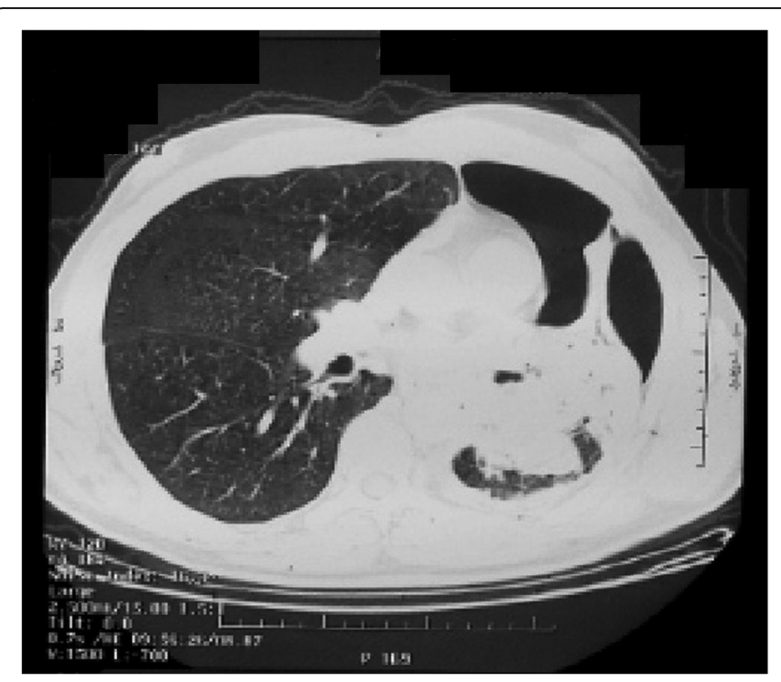

Fig. 2 CT-Chest (pulmonary window) showing a large left lung mass, measuring about $7 \times 5.5 \times 4.5 \mathrm{~cm}$ showing cavitations with thick irregular walls and foci of air

one patient, out of the four had bullectomy for large lung bulla; the surgeon felt a small nodule at the junction of the lung bulla and the normal remaining lung tissue during the surgical procedure. This nodule was resected with the lung bulla, and frozen section examination revealed a primary lung cancer. Hence, surgeon decided to proceed into formal lobectomy. Eighteen patients out of the twenty-three $(78 \%)$ were smokers. For the nineteen patients who were preoperatively diagnosed with primary lung cancer, seven patients of them (36.8\%) had an adenocarcinoma while twelve patients of them $(63.2 \%)$ had squamous cell NSCLC. The preoperative staging revealed that $5.3 \%$ had stage IIA, $21.1 \%$ had stage IIB, $26.3 \%$ had stage IIIA, and $47.4 \%$ had stage IIIB NSCLC. Six patients out of the nineteen $(31.6 \%)$ had surgical pulmonary resection following primary intervention for the pneumothorax for treatment of NSCLC. Surgery performed was in the form of lobectomy $(n=5)$ and pneumonectomy $(n=1)$. No perioperative mortality was encountered. Complications were found in three patients; one patient had post-operative cardiac arrhythmia, and two patients had superficial wound infection. Table 1 showed the demographic data of the studied group.

For facilitating discussion of the results, authors have divided the patients into four groups. This classification was not intended during planning for the methodology of the research protocol. Group I included patients who were diagnosed with primary lung cancer and were receiving chemotherapy, radiotherapy, or both, and they had SPnx during the course of their treatment. Group II included patients who had SPnx first, and primary lung cancer was discovered during investigations performed. 
Table 1 Demographic data

\begin{tabular}{|c|c|c|c|c|c|c|c|c|c|c|}
\hline No. & Sex & Age & $\begin{array}{l}\text { Initial } \\
\text { Dx. }\end{array}$ & Stage & Smoking & $\begin{array}{l}\text { On } \\
\text { therapy }\end{array}$ & $\begin{array}{l}\text { Pnx during course of } \\
\text { treatment }\end{array}$ & $\begin{array}{l}\text { Pnx as primary } \\
\text { presentation }\end{array}$ & Surgery & Type of surgery \\
\hline \multicolumn{11}{|c|}{ Group I } \\
\hline 1 & M & 65 & LSCC & $\| \mathrm{IIB}$ & Y & Y & Y & N & $\mathrm{N}$ & \\
\hline 2 & M & 60 & LSCC & $\| \mathrm{IIB}$ & Y & Y & Y & N & $N$ & \\
\hline 3 & $\mathrm{~F}$ & 59 & LAC & $\| I B$ & $\mathrm{~N}$ & Y & Y & N & $N$ & \\
\hline 4 & M & 70 & LSCC & $\| I B$ & Y & Y & Y & N & $\mathrm{N}$ & \\
\hline 5 & M & 66 & LSCC & $\| I A$ & Y & Y & Y & N & $\mathrm{N}$ & \\
\hline 6 & M & 77 & LAC & $\| \mathrm{A}$ & Y & Y & Y & $N$ & $\mathrm{~N}$ & Pneumonectomy \\
\hline 7 & M & 54 & LSCC & $\| I \mid B$ & Y & Y & Y & N & Y & \\
\hline 8 & $\mathrm{~F}$ & 67 & LAC & $\| \mathrm{II}$ & $\mathrm{N}$ & Y & Y & $N$ & $\mathrm{~N}$ & \\
\hline 9 & M & 66 & LSCC & $\| \mathrm{IIB}$ & Y & Y & Y & $\mathrm{N}$ & $\mathrm{N}$ & \\
\hline 10 & $\mathrm{~F}$ & 59 & LSCC & $\| \mathrm{A}$ & Y & Y & Y & $\mathrm{N}$ & $\mathrm{N}$ & \\
\hline 11 & M & 60 & LSCC & $\| \mathrm{IIB}$ & Y & Y & Y & N & $\mathrm{N}$ & \\
\hline 12 & M & 71 & LSCC & $\||| B$ & Y & Y & Y & N & $\mathrm{N}$ & \\
\hline \multicolumn{11}{|c|}{ Group II } \\
\hline 13 & M & 62 & LSCC & $\| \mathrm{B}$ & Y & $\mathrm{N}$ & $\mathrm{N}$ & Y & Y & Lobectomy \\
\hline 14 & M & 63 & LAC & $\| \mathrm{B}$ & Y & $N$ & $\mathrm{~N}$ & Y & Y & Lobectomy \\
\hline 15 & M & 59 & LAC & $\| \mathrm{B}$ & Y & $\mathrm{N}$ & $\mathrm{N}$ & Y & Y & Lobectomy \\
\hline 16 & M & 65 & LSCC & $\| I A$ & Y & $\mathrm{N}$ & $\mathrm{N}$ & Y & $\mathrm{N}$ & \\
\hline 17 & M & 59 & LAC & $\| \mathrm{B}$ & $N$ & $N$ & $\mathrm{~N}$ & Y & Y & Lobectomy \\
\hline 18 & $\mathrm{~F}$ & 73 & LAC & $\| \mathrm{A}$ & $N$ & $\mathrm{~N}$ & $\mathrm{~N}$ & Y & $\mathrm{N}$ & \\
\hline 19 & M & 69 & LSCC & $\| \mathrm{A}$ & $N$ & $N$ & $\mathrm{~N}$ & Y & Y & Lobectomy \\
\hline \multicolumn{11}{|c|}{ Group III } \\
\hline 20 & $\mathrm{~F}$ & 56 & Rec.SPnx & N/A & Y & $N$ & $\mathrm{~N}$ & Y & Y & $\begin{array}{l}\text { Bullectomy and } \\
\text { lobectomy }\end{array}$ \\
\hline 21 & M & 49 & $\begin{array}{l}\text { Rec. } \\
\text { SPnx }\end{array}$ & N/A & Y & $N$ & $\mathrm{~N}$ & Y & Y & $\begin{array}{l}\text { Bullectomy and } \\
\text { lobectomy }\end{array}$ \\
\hline 22 & M & 48 & Rec.SPnx & N/A & Y & $N$ & $\mathrm{~N}$ & Y & Y & $\begin{array}{l}\text { Bullectomy and } \\
\text { lobectomy }\end{array}$ \\
\hline \multicolumn{11}{|c|}{ Group IV } \\
\hline 23 & $\mathrm{~F}$ & 56 & $\begin{array}{l}\text { Rec. } \\
\text { SPnx }\end{array}$ & N/A & Y & $\mathrm{N}$ & $\mathrm{N}$ & Y & Y & $\begin{array}{l}\text { Bullectomy and } \\
\text { lobectomy }\end{array}$ \\
\hline
\end{tabular}

$M$ male, $F$ female, Initial $D x$. initial diagnosis, LSCC lung squamous cell carcinoma, LAC lung adenocarcinoma, Rec. SPnx recurrent spontaneous pneumothorax, $Y$ yes, $N$ no

Group III included patients who were presented with SPnx, and an evident lung bullae at chest X-ray or chest-CT and post-operative histo-pathological examination of the resected lung bullae revealed an early primary lung cancer. While group IV included patients, who were presented with SPnx and lung bullae, and the primary lung cancer was discovered accidently at the operating room during resection of the bullae.

\section{Group I}

This group included twelve patients, three females and nine males. Age ranged between 54 and 77 years old 
(64.5 \pm 6.4 years). Patients with stage IIIB constituted $75 \%$ of patients in this group, while $25 \%$ of them had stage IIIA. The majority of patients $(75 \%)$ had squamous cell lung cancer while $25 \%$ had adenocarcinoma. All patients except one had a smoking history. All of the patients had primary intervention for SPnx (pigtail and underwater seal; $n=3$; intercostal drain and underwater seal; $n=9$ ). Four patients (33.3\%) had prolonged air leak, and they received blood patch. One of the three patients with stage IIIA had formal pneumonectomy later following down staging via preoperative chemo-radiotherapy.

\section{Group II}

Seven patients were included in this group; six patients $(85.7 \%)$ were males. Age ranged between 59 and 73 years old (64.3 \pm 5.2 years). All patients presented with SPnx, and the diagnosis of associated primary lung cancer was established during the management of SPnx. Four patients (57.1\%) had a history of smoking. Stage IIB was the most frequently encountered stage in this group (57.1\%) while stage IIA was found in one patient and stage IIIA in two patients. Pathological subtypes of NSCLC were either squamous cell lung cancer (42.9\%) or adenocarcinoma of the lung (57.1\%). All patients were managed for pneumothorax (insertion of pigtail and underwater seal $(n=1)$ and insertion of intercostal drain and underwater seal $(n=6))$. One patient had prolonged air leak, and blood patch was performed. Most of patients (71.4\%) included in this group had further management for lung cancer in the form of lobectomy.

\section{Group III}

This group included three patients. Two patients (66.7\%) were males. Age ranged between 48 and 56 years $(51 \pm$ 4.4 years). These patients were presented with SPnx, and investigations revealed bullous lung disease. Following bullectomy, histo-pathological examination revealed primary lung cancer at the specimen of the resected lung bullae. All patients had an intercostal drain primarily inserted and underwater seal followed by video-assisted bullectomy. Following the pathology reports, all patients (100\%) had surgical management of NSCLC in the form of lobectomy.

\section{Group IV}

This group includes one patient (female; smoker, 56 years old), who presented initially with SPnx and bullous lung disease. Intercostal drain and underwater seal was inserted. Bullectomy was scheduled and during the procedure, the surgeon felt a small nodule at the base of the large lung bulla. The nodule was included in the resected bullae. The specimen was sent for frozen section and pathological examination. Pathology revealed primary NSCLC. Lobectomy was performed at the same setting, and final pathological examination revealed brocho-alveolar carcinoma.

\section{Discussion}

SPnx could be either primary or secondary. Primary SPnx mostly affects healthy young adults while the secondary SPnx can develops as a result of bronchial obstruction, infarction, infection, neoplasm, or diffuse lung diseases [7]. SPnx as a complication of pulmonary carcinoma is rare $[7,12,17]$. Only $2 \%$ of all SPnx coexist with malignant lung diseases either primary or secondary. This tumor complication must be suspected in older patients [18]. In our series, the incidence of the primary lung cancer associated with SPnx was found to be $0.9 \%$.

Only few small series and some case reports were published about SPnx occurring in association with primary pulmonary carcinoma. The largest four series $[4,5,18$, $19]$ in the literature are listed in Table 2. The largest one was that published by Cicénas et al. on 2011 that included 27 patients [18]. Our retrospective study included 23 patients during 18 years.

Several theories have been published in the literature regarding the mechanisms of the occurrence of the SPnx in patients with primary lung cancer. The first theory explained that pneumothorax could be due to necrosis of the cancer that directly ruptured into the pleural space [13]. This may be what is actually happened to some patients in group I and II who presented with a mass lesion that showed necrosis and air cavities. The second theory stated that endobronchial neoplasm could act as a check-valve that leads to dilatation and eventual rupture of the distal alveolar spaces [20]. This theory could explain the occurrence of the pneumothorax in some of patients who had partial obstruction of the lobar bronchus with the tumor that was evident at the radiological investigations. Majority of these patients were included in group II. The third theory stated that pneumothorax may arise from rupture of small subpleural blebs, and this may explain the occurrence of pneumothorax in the three patients included in group III. Fourth theory proposed that most patients with lung cancer have chronic obstructing pulmonary disease (COPD) or emphysematous bullae that may rupture following the disturbance of the pulmonary architecture due to bronchial carcinoma [7, 20]. This theory may explain the SPnx in the patient who had SPnx, and pathological examination revealed a pulmonary carcinoma at the base of excised large lung bulla.

In the majority of our patients, it was noted that the stage of lung cancer is advanced, stage IIIB $(n=9)$ and stage IIIA $(n=5)$. Laurens et al. [21] documented that the association of SPnx with lung cancer is an ominous 
Table 2 Largest publications documented pneumothorax in association with primary lung cancer

\begin{tabular}{lllll}
\hline Serial & Author & Publication year & Duration of the study & Number of patients \\
\hline 1 & Yilmaz et al. [4] & 2005 & N/A* & 5 \\
2 & Stienhauslin et al. [5] & 1985 & $1959-1983$ & 6 \\
3 & Cicénas et al. [18] & 2011 & $1970-2009$ & 27 \\
4 & Citron et al. [19] & 1959 & N/A* & 6 \\
\hline
\end{tabular}

${ }^{*} \mathrm{~N} / \mathrm{A}=$ Non-applicable

sign. He explained this bad prognostic association by vascular invasion mechanism during the process of the tumor necrosis. However, this could not be confirmed at our study. Moreover, in four patients included in our series, the SPnx and surgery for emphysematous bulla helped to early discover the pulmonary carcinoma, and this is infrequent. Finally, there are some limitations in this study including that it is a retrospective study, small number of patients is included, and wide period that extended to 18 years. Moreover, some missing clinical data could not be obtained from the patient files especially old ones.

\section{Conclusion}

In conclusion, SPnx is a rare association with primary lung cancer. It could complicate advanced stages of pulmonary carcinoma. SPx occurring in heavy smokers, elderly patients with emphysema can be an alert for thoracic surgeons to exclude pulmonary carcinoma. However, SPnx in patients with lung cancer could not be proved an ominous sign, and its relation to final diagnosis should be furtherly investigated.

\section{Abbreviations}

SPnx: Spontanous pneumothorax; NSCLC: Non-small cell lung cancer; COPD: Chronic obstructive pulmonary disease

\section{Acknowledgements}

N/A

\section{Authors' contributions}

WA has made substantial contributions to the design of the work and the acquisition, analysis, and interpretation of the data and has drafted the work and revised it. AR has made substantial contributions to the design of the work and interpretation of the data and revised the draft. Authors have approved the submitted manuscript for publication and have agreed both to be personally accountable for the author's own contributions and to ensure that questions related to the accuracy or integrity of any part of the work, even ones in which the author was not personally involved, are appropriately investigated, resolved, and the resolution documented in the literature.

\section{Funding}

None declared

Availability of data and materials

Data and materials are available upon request.

\section{Ethics approval and consent to participate}

Approval from the Ethical Research Committee of the Faculty of Medicine, University of Alexandria was obtained before conduction of research.

\section{Consent for publication}

N/A

\section{Competing interests}

None declared.

Received: 14 January 2020 Accepted: 3 April 2020

Published online: 16 April 2020

\section{References}

1. Solak O, Sayar A, Metin M, Turna A, Pekçolakar A, Gurses A (2006) Bronchial carcinoma presenting with pneumothorax. Eur J Med 3(2):78-79

2. Choi YK, Kim KC (2015) Spontaneous pneumothorax as the first manifestation of lung cancer: two case report. Journal of thoracic disease 7(8):E252

3. De Barrin J (1937) Haemopneumothorax spontane dans une metastase pulmonaire de sarcoma osseux. Bull Mem Soc Radiol Fr 25:73

4. Yilmaz A, Akkaya E, Guneylioğlu D, Duzgun S (2005) Spontaneous pneumothorax complicating primary lung cancer: analysis of five cases. Turkish Respiratory Journal 6(1):56-58

5. Steinhauslin CA, Cuttat JF (1985) Spontaneous pneumothorax: a complication of lung cancer? Chest 88:709-713

6. Ohata M, Suzuki H (1980) Pathogenesis of spontaneous pneumothorax with special reference to the ultrastructure of emphysematous bullae. Chest 77 : 771-776

7. Vencevičius V, Cicénas S (2009) Spontaneous pneumothorax as a first sign of pulmonary carcinoma. World Journal of Surgical Oncology 7:57-59

8. Bauman MH, Noppen M (2004) Pneumothorax. Respiratory 9:157-164

9. Dines DE, Cortese DA, Brennan MD, Hahn RG, Payne WS (1973) Malignant pulmonary neoplasms predisposing to spontaneous pneumothorax. Mayo Clin Proc 48:541-544

10. Hoag JB, Sherman M, Fasihuddin Q, Lund ME (2010) A comprehensive review of spontaneous pneumothorax complicating sarcoma. Chest. 138(3): 510-518

11. Fayda M, Kebudi R, Dizdar Y, Gorgun O, Gun F, Aksu G, Ayan I (2012) Spontaneous pneumothorax in children with osteosarcoma: report of three cases and review of the literature. Acta Chir Belg 112(5):378-381

12. Galbis CJM, Mafe MJJ, Baschwitz GB, Perez CA, Rodriguez PJM (2001) Spontaneous pneumothorax as the first sign of pulmonary carcinoma. Arch Bronconeumol 37:397-400

13. Minami H, Sakai S, Watanabe A, Shimokata K (1991) Check-valve mechanism as a cause of bilateral spontaneous pneumothorax complicating bronchioloalveolar cell carcinoma. Chest 100:853-855

14. Mahajan V, Kupferer CF, Van Ordstrand HS (1975) Pneumothorax: a rare manifestation of primary lung cancer. Chest 68:730-732

15. Arab WS, Abdel-Aziz AM, Ramadan AM (2015) Spontaneous pneumothorax associated with primary lung cancer. In Journal of cardiothoracic surgery 10(1):A242

16. Kurokawa T, Morikawa T, Ohtake S, Kaji M, Sugiura H, Okushiba S, Kondo S, Katoh H (2002) Spontaneous pneumothorax secondary to radiographically occult lung metastasis from parapharyngeal synovial sarcoma: report of a case. Surg Today 32:267-269

17. O'Connor BM, Ziegler P, Spaulding MB (1992) Spontaneous pneumothorax in small cell lung cancer. Chest 102(2):628-629

18. Cicénas $S$, Vencevičius V (2011) Malignant pulmonary neoplasms predisposing to pneumothorax. Acta Medica Lituanica 18(2):53-55

19. Citron KM (1959) Spontaneous pneumothorax complicating bronchial carcinomas. Tubercle 40:384 
20. Okada D, Koizumi K, Haraguchi S, Kawamoto M, Mikami I, Tanaka S (2002) Pneumothorax manifesting primary lung cancer. J Thorac Cardiovasc Surg 50(3):133-136

21. Laurens RG Jr, Pine JR, Honig EG (1983) Spontaneous pneumothorax in primary cavitating lung carcinoma. Radiology 146:295-297

\section{Publisher's Note}

Springer Nature remains neutral with regard to jurisdictional claims in published maps and institutional affiliations.

Submit your manuscript to a SpringerOpen ${ }^{\mathcal{O}}$ journal and benefit from:

- Convenient online submission

- Rigorous peer review

- Open access: articles freely available online

- High visibility within the field

- Retaining the copyright to your article

Submit your next manuscript at $\boldsymbol{\wedge}$ springeropen.com 